\title{
An analytical review on rethinking service-learning as critical transformative paradigm in higher education
}

\author{
Muhammad Saeed*1 ${ }^{*}$ Iqbal Ahmed ${ }^{2}$ \\ 1. Department of Global Studies, King Fahd University of Petroleum \& Minerals, Saudi Arabia. \\ 2. Department of Education, University of Malakand, Chakdara, Dir Lower, Pakistan. \\ *Corresponding Author Emails: msaeedpk@kfupm.edu.sa | saeeddir@gmail.com \\ Received: October 1, 2021 \\ Published: December 31, 2021
}

\begin{abstract}
In recent times, service-learning has emerged as a popular community-based instructional pedagogy. However, scholars have a sharp contention about the role of service-learning as a community engagement paradigm in higher education. Furthermore, limited studies exist on service-learning as a transformative instructional pedagogy in higher education. This paper addresses this gap in the literature by presenting an analytical review on the potential of servicelearning as a transformative pedagogy in higher education. A traditional narrative review method was used to survey on the theme of the study to establish a theoretical framework and draw conclusions. An extensive survey of existing literature was conducted on the role of servicelearning as transformative pedagogy in higher education. This research may help answer the following two critical questions: What are internal and external limits to service-learning in higher education? To what extent can service-learning replace the traditional mode of teaching and learning in higher education successfully? The review shows that service-learning is a critical transformative pedagogy that helps achieve the boarder goals of higher education in a more effective way. The review further informs that service-learning is a community engagement approach that can also be used as a teaching method for achieving specific civic and democratic goals of higher education.
\end{abstract}

Keywords: service-learning, transformative paradigm, higher education, community engagement, instructional pedagogy.

How to Cite: Saeed, M., \& Ahmed. I (2021). An analytical review on rethinking service-learning as critical transformative paradigm in higher education. Journal of Humanities, Social and Management Sciences (JHSMS), 2(2), 318-334. https://doi.org/10.47264/idea.jhsms/2.2.23

Publisher's Note: IDEA PUBLISHERS (IDEA Publications Group) stands neutral regarding jurisdictional claims in the published maps and institutional affiliations.

Copyright: ( 2021 The Author(s), published by IDEA PUBLISHERS (IDEA Publications Group).

Licensing: This is an Open Access article published under the Creative Commons AttributionNonCommercial 4.0 International License (http://creativecommons.org/licenses/by-nc/4.0/) 


\section{Introduction}

Service-learning has become a popular critical pedagogy. It is a credit-bearing and experiential educational method that allows students to collaborate, develop a sense of civic responsibility, gain new knowledge and skills by reflecting on the service acidity, and provide service to the community (Bringle \& Hatcher, 1995). It is an educational method that connects community service objectives with academic content (Bringle \& Hatcher, 1995). It benefits both the student and the community. For example, students find learning opportunities, and the community gets the service (Bringle \& Hatcher, 1995). It is a structured program based on self-reflection, selfdiscovery, acquisition, and comprehension of values, skills, and knowledge (Mortari \& Ubbiali, 2021). Studies have documented the service-learning benefits such as flourishing leadership skills, problem-solving skills, interpersonal skills, social and moral development, and civic responsibility and teamwork skills (Culhane et al., 2018).

Higher education embeds service-learning as a prime engaging paradigm (Tian \& Noel, 2020). In particular, it has achieved the status of becoming the standard-bearer for civic renewal and community engagement (Berle, 2006). This is a beautiful affirmation of the progress of servicelearning as an engaged pedagogy for the last three decades (Bell et al., 2000). In addition, scholars have declared it a philosophy and pedagogy due to its typical nature of linking classrooms with the communities (Salam, et al., 2019). Furthermore, Ernest Boyer (1996) has termed it the 'scholarship of engagement' as it connects research and teaching to foster individual and community change (Colbeck \& Michael, 2006; Harkavy, 2006).

Service-learning has earned a unique reputation being a solid community engagement pedagogy in the academic world (Bryant et al., 2011; Butin, 2010; Melchior, 2000). It has successfully bridged the long-prevailing gap between theory and practice of traditional teaching and learning in higher education (Antonio et al., 2000; Rhoads, 1997). One of the significant contributions of service-learning is linking academic content with community service within a framework of respect, reciprocity, relevance, and reflection (Berle, 2006; Liu, 1995). As a result, it has gained tremendous popularity in the last two decades as a form of active and experiential civic pedagogy in higher education. Numerous writers have even called this a community engagement movement because it successfully integrates traditional learning with community experience, develops students' academic achievements and cultural competence, and fosters a just and inclusive world (Tijsma et al., 2020; Morgan \& Streb, 2001; Varolta, 1997).

Research has revealed that higher education institutions have realized the potential of servicelearning for creating sustainable partnerships with local communities and is being considered a robust predictor of students' deep civic learning (Saeed \& Ahmed, 2021; Butin, 2005; Furco, 2002). Current higher education institutions seem more inclined toward adopting collaborative approaches, learning models, and standardized practices as techniques for effective teaching and learning. This aim could be best achieved through service-learning because, as a collaborative practice, service-learning allows higher education institutions to expand their practices and priorities beyond the traditional boundary wall of classrooms into the communities. The service activities can be effectively aligned with collaborative community practices (Hartley et al., 2005).

The service-learning has currently positioned itself in the higher education as transformational 
An analytical review on rethinking service-learning as critical transformative paradigm ...

community-based learning approach (Lindholm et al., 2005). More than one thousand postsecondary memberships of the campus compact are committed to community service, civic engagement, and service-learning in higher education worldwide. Enormous research has suggested that service-learning is a beneficial pedagogical intervention for promoting a more comprehensive range of outcome variables such as academic achievements, civic engagement, diversity attitude, and so on (Jones et al.,2005). This practice has become a recognized marker in higher education. Due to this, it has attracted the attention of scholars, practitioners, and students from multiple disciplines of higher education towards its exciting pedagogical opportunities (Driscroll, 2008; Butin, 2006).

The service-learning paradigm has gained the interest of scholars concerning its legitimization and institutionalization in higher education (Resch et al., 2020). However, rather than attempting its merits, researchers have shifted their focus on the modes and means by which service-learning can be integrated as a viable academic methodology in higher across disciplines (Hartley et al., 2005; Furco, 2002). Moreover, many researchers have called for a more public participatory scholarship to extend further the Boyers' call for 'scholarship of engagement' in higher education, which is academically rigorous, engaged, helpful, and responsive (Colby et al.,2007a and 2007b; Ramaley, 2006). This paper suggests that, unlike the traditional practices, the theory and practice in the higher education are turning to new dimensions such as collaboration, engagement, and partnership. This paper therefore investigates this area using the service-learning as a collaborative and engaged paradigm (Lough \& Toms, 2018).

For this purpose, this paper attempts to answer the following questions: What are the internal and external limits to service-learning in higher education? How do different perspectives explain the possibilities of service-learning to help achieve higher educational goals within a disciplinary context? How can service-learning be used as critical pedagogy in higher education? Scholars have attempted to find answers to these from various perspectives at different levels of education. In the backdrop of this, although previous studies have extensively explored the outcomes perspective of service-learning, very few studies have ventured into the conceptualization of service-learning from its technical perspective as community engagement civic pedagogy in higher education (Mitchell, 2007). Therefore, the primary objective of this paper is to review the technical standpoint of service-learning as a critical paradigm in higher education and explain its conceptualization from a technical aspect. Also, this article attempts to challenge some of the assumptions about service-learning as a critical pedagogy in higher education.

This study has used the narrative analysis approach (see, e.g., Butina, 2015; Esin, 2011) for answering the following research questions: What are internal and external limits to servicelearning as critical pedagogy in higher education? To what extent can service-learning replace the traditional mode of teaching and learning in higher education? How do different perspectives explain the possibilities of service-learning to help achieve higher educational goals within a disciplinary context?

Narrative Analysis is a qualitative investigative approach that helps analyse current scholarship on a topic. In addition, it helps establish a theoretical framework and clear focus or context for the research (Greenlaglgh et al., 2018). 


\section{Theoretical framework}

The concept of service-learning emerged from the experiential educational thoughts of John Dewey in the early 60s in general and Robert Sigmon and William Ramsey in the late 1970s. Since then, service-learning has gained wider popularity as an experiential teaching method for fostering civic growth and contributing to the community through organized service (WarrenGordon \& Graff, 2018). John Dewey considered experience and practical engagement the foundation of effective learning and development. Further, Dewey believed that students will learn better citizenship skills when they are engaged in community service-learning (Rodríguez-Izquierdo, 2020). Dewey argued that students' experiences in traditional education are not effective due to their inadequate connectivity to real-life situations. It means that students need active learning that focuses on knowledge and practice (Gruslyte, 2020). Being an experiential learning pedagogy, service-learning best facilitates the materialization of this goal. Dewey's theory of experimentalism provides some understanding of the process of service-learning. He connected service-learning to social philosophy, the issues of citizenship, community and democracy. He explored very close relationship between learning and service. His famous pragmatic philosophy associates knowledge with action and individual to society, which was further articulated by his theory of experimentalism. Thus, his educational thoughts provide basic principles for civic participation and democracy which further cemented the concept of service-learning (Folgueiras et al., 2020).

As mentioned above, service-learning became popular during the last two decades. In the mid of 1980s, it was rapidly practiced in college campuses with a national drive to promote a sense of service among the school graduates (National Commission on Service Learning, N.D). Interestingly, by 1999 , more than $32 \%$ of the public schools worldwide had integrated servicelearning in their courses (National Commission on Service Learning, N.D). The popularity of service-learning grew to the extent in 2003 that World Reports Magazine had listed many colleges and universities in the US incorporating service-learning in their courses (Gruslyte, 2020). Moreover, apart from Dewey, service-learning also derives from the works of Jane Addams and Dorothy Day. Addams established a helping center for the poor called Hull house. Dorothy, a social activist, fought for the rights of the disadvantaged. Due to the efforts of these activists, the concept of service-learning began to take roots as an educational practice in the early 60s and finally appeared in the 70s. Later on, many organizations, such as the National Student Volunteer Programme and National Centre for Service-Learning, adopted it because of its many benefits as an educational method (Taylor \& Kahlke, 2017). Among all the theories that contributed towards the development of service-learning, the experiential learning theory of David Kolb provides a fundamental foundation on which the grand edifice of servicelearning stands. Like Dewey, Kolb also explains that learning occurs through experience. It is a cycle that comprises action, reflection, exploration, and thinking. This cycle allows students to construct new knowledge from experience. Service-learning also includes a process in which planning, implementation, reflection, and reporting provide a basis for learning and development (Folgueiras et al., 2020).

The Piaget's concept of education also emphasized service-learning practice. According to him, an individual interacts with the environment and constructs meaning out of the experience. Piaget calls this accommodation. He emphasizes it as helpful in discerning the process of service-learning (Hildenbrand \& Schultz, 2015). Similarly, Erickson posited that interaction with the environment is central to the psychosocial development of individuals. The famous 
An analytical review on rethinking service-learning as critical transformative paradigm ...

Brazilian educator Paulo Freire also contributed to service-learning. His educational goals included the political transformation of individuals and society through literacy, education, critical reflection, and collective social action. His educational philosophy stresses experience, growth, inquiry, communication, mediation, problem-solving, raising awareness, and transformation. All this provided theoretical enrichment to the concept of service learning (Berasategi et al., 2016).

The above discussion clearly shows that much of the theory related to service-learning programs have evolved from the experiential learning models. Experiential learning is a process through which a learner constructs knowledge, skills, and values from experience (Folgueiras et al., 2020). Thus, service-learning enables the students to apply their learning in the community, get expertise, construct and reconstruct their knowledge. For example, in 1938, Dewey presented his experiential learning theory that explained the different stages in the problem-solving process: encountering the problem, defining the problem, collecting information, assessing information, developing a hypothesis, testing the hypothesis, and drawing conclusions (Lorenzo \& Lorenzo, 2019). According to Dewey, the main aim of education is developing students' reasoning capacities and problem-solving skills. This thinking is based on the theory of constructivism. Constructivist learning stresses the utilization of experience, collaboration, and reflection to assist learners in confronting problems and solving them. Research has revealed that students become motivated when learning improves their abilities to solve real-life problems. Dewey also empathized with a learning environment promoting problem-solving and innovation. Though learning is an individual experience, studies have shown that people learn by interaction with others and in collaborations (Conner \& Erickson, 2017).

\section{Service-learning in higher education: An analysis}

A significant paradigm shift has occurred due to rapid industrialization, democratization, marketization, and globalization (O'Grady, 2000; Paul, 2006). Specifically, these developments have posed new limitations and possibilities to higher education and the communities. This has caused a fundamental drift and rethinking among researchers, scholars, and practitioners about the values and mission of higher education. In addition, the trend has further created anxiety among scholars about higher education's renewed goals and role regarding the public good and community development (Bensen et al., 2007; Colby et al.,2007b; Kezar et al., 2005; Zemsky et al.,2005; Kirp, 2003). This rethinking has further intensified due to the increasingly lowering position of traditional education (Pompa, 2002). As a result, people, communities, stakeholders, and practitioners alike question the ability of conventional higher education to deliver effectively to the increased needs of the current times (Pompa, 2005). On the other sides, there is a general expectation among all the stakeholders regarding the increasing weaknesses in the existing higher education practices to develop required abilities and capabilities among the students. The widespread allegations on the traditional higher education are its inability to establish a sense of inquiry, critical thinking, civic engagement, and social responsibility among students (Vaughn \& Seifer, 2008; AAC\&U, 2007).

The rapid expansion in service-learning in the last decade has created many questions about its ability to sustain the pressures of higher education and its challenges. In this regard, scholars ask many questions (Young et al., 2007). For example, first, whether traditional higher education can deal with the current challenges of the communities worldwide. Second, how far 
has the current higher education responded effectively to the ever-increasing diverse needs of the communities due to globalization and its implications in varying forms? Studies have argued that service-learning, as a social moment, has long been tested and found not sufficient for rectifying the increasingly diverse needs of communities and addressing the complexities and problems of higher education in the current times (Head, 2007; Swaminathan, 2007; Schutz, 2006; Hogan, 2002). Literature has provided three reasons for rethinking in servicelearning about the role of higher education and community engagement. First, the current practices and strategies in higher education are being guided by the old assumptions, carried by the teachers, students, and communities alike, to produce scholars for the community who have 'knowledge of the world.' Second, practitioners have now developed a sense that an engaging and transformative pedagogical model is required to effectively deal with modern communities' expectations and multidimensional needs. Third, if service-learning did not effectively grapple with its technical issues, there is the likelihood that others would fill the gap. For example, there is a profound ongoing debate about the need for intellectual diversity in higher education. It is believed that the existing traditional model of higher education promotes only indoctrination rather than education (Borden, 2007). Other researchers (see, e.g., Baldwin et al., 2007; Paoletti, 2007) argue that service-learning being a transformative engaged pedagogy can bridge this gap in the theory and practice of higher education. They state that service-learning is a powerful form of experiential pedagogy that can lead to communities, students, and scholars rethinking their views on the larger vision of community engagement in higher education (Baldwin et al., 2007; Paoletti, 2007).

\subsection{Service-learning defined}

Service-learning is a "course-based, credit-bearing educational experience that allows students to (a) participate in an organized service activity that meets identified community needs and (b) reflect on the service activity in such a way as to gain further understanding of course content, a broader appreciation of the discipline, and an enhanced sense of civic responsibility" (Bringle \& Hatcher, 1995: 112). Presently there is a growing awareness among scholars regarding the role of higher education institutions around the globe (Butin, 2010; Ellison \& Eatman, 2008; Zlotowski, 1995). The result of such development is that higher education institutions have embarked on redefining and rethinking their responsibilities and commitment to community engagement for the civic development of citizens. This trend has intensified research on community-based learning. As a result, service-learning as a community-based engaged pedagogy has received much attention over the last decades (Eyler, 2000). For example, in 1990, the National and Community Service Act was enacted in the United States to increase civic participation in higher education. Later on, in 1993, Corporation for National and Community Service was formed to mobilize Americans for community service (Bryant et al., 2011; Lucas, 1996).

More than 500 leaders in US higher education institutions have signed the President's Declaration on the Civic Responsibility of Higher Education. The essential purpose of this movement is to reinvigorate and highlight the civic mission of higher education (Campus Compact, 2005). Service-learning was primarily valued for its traditional role in promoting students' better understanding of theoretical concepts. However, more recently, it was realized that it could also offer other significant benefits, such as enabling students to explore connecting classroom theory to practical needs of the community in real-life situations. This helps reinforce students' critical thinking, communication, teamwork skills. However, service- 
An analytical review on rethinking service-learning as critical transformative paradigm ...

learning's most vital long-term benefit is providing students a handy opportunity to connect to the community and identify their civic roles (Bryant et al., 2011; Campus Compact, 2003).

These benefits mentioned above of service-learning have attracted the attention of researchers and practitioners. However, scholars have faced many limitations besides its benefits. For example, constructing and implementing service-learning is a time-consuming and daunting task in higher education. But research has revealed that these limitations can be overcome by searching out new possibilities. One such possibility is following specific approaches within service-learning theory (Bryant et al., 2011). For example, 'course portfolio' can be used as a 'pedagogical model' to record students' reflections during the service activity for meeting the needs mentioned above. Reflection is a critical element of service-learning. Through reflection, students understand the deeper connections between the theory and practice of education. This further leads to a deeper understanding of the course as well as the community needs. This combination of service and learning provides a sound basis for the development of both students and the community equally (Bryant et al., 2011; Eyler \& Giles, 1999; Honnet-Porter \& Poulson, 1989).

Within the framework provided by Bernstein et al. (2006), course portfolios can be used for a variety of academic purposes in higher education such as promotions, tenure decisions, course design, and assessment, as well as a foundation for more comprehensive inquiries into the effectiveness of pedagogical approaches (Bernstein et al.,2006). Typically, the course portfolios are portioned into four parts: (1) Profile of course and students, (2) statement of learning goals, (3) methods and approaches to be used and, (4) evidence of success or failure of the approaches in meeting the set instructional goals of the specific course (Bernstein et al.,2006). The rationale behind selecting the model and instructional choice and the various notions of teaching and learning play a crucial role in developing examples for successful community engagement interventions. It must be kept in mind that presenting one example will not be effective (Bryant et al., 2011; Bell et al., 2000; Wade, 2007). Based on the above discussion, it can be argued here that there is a need to explore a multi-disciplinary model for implementing service-learning in higher education. The nature of service-learning as a multidisciplinary approach also supports this notion. This would make it possible to develop a multidisciplinary model to meet other multi-cultural communities' needs in different contexts.

Experience and reflection play a central role in learning in a service-learning process. As a result of service experience, students have improved comprehension of course material, higherorder thinking and critical examination of problems and issues, and a more profound sense of community engagement (Markus et al., 1993). To find the answer to these notions, we should re-visit and rethink the very nature of service-learning, whether it is pedagogy or a philosophy. Can it change a community? Can it transform a classroom from more theocratic to practical? What are the limits of service-learning in this regard?

Literature on service-learning tries to answer these questions in multiple ways. However, the standard argument is that service-learning pedagogy nullifies and rejects the 'Banking Model' of education, emphasizing theory at the cost of practice. In this model, the transformation takes place in the shape of transferring knowledge from teacher to student. It does not allow the students to think on the new knowledge critically. Thus, the result of this model is the development of 'passive mind' instead of 'active mind,' which is the primary goal of servicelearning (Butin, 2010; Astin et al., 1999). On the other hand, some writers argue that service- 
learning as an active pedagogy has gained much fame and name in current higher education. Some writers genuinely consider it a means of re-engaging students with academics and civic values for polishing their skills to become active community members (Colby et al., 2007a).

Many service-learning advocates have pointed towards some other benefits attached with service-learning in all three domains of education: cognitive, affective, and psychomotive. For example, service-learning fosters a more active citizenry (Bensen et al., 2007). In the same way, Astin et al. (1999) argued that it genuinely promotes scholarship of engagement that supports a more equitable society and achieves social justice goals. More importantly, Wade (2007) posited that service-learning as a reciprocal approach is ideal in connecting colleges and universities with the communities. Further, it promotes mutual interests and meets their diverse needs by emphasizing real-world learning and creating a genuine relationship between all the stakeholders in higher education (Wade, 2007).

Butin (2010) documents that, despite the recent proliferation of research on the merits of service-learning as a community-based approach toward education, its expansion has many challenges in terms of theory and practice. For example, there is still ambiguity about servicelearning's basic principles and goals. In this regard, the main question is whether servicelearning is a pedagogical approach for better course comprehension or merely a philosophical stance to elevate community cause? Furthermore, even some critics have realized its voyeuristic exploitation of cultures and communities (Cross, 2005; McKnight, 1998). These perspectives provide more grounds for sound discussion on the true nature of service-learning as a community-based pedagogical paradigm.

\subsection{Service-learning as a transformative paradigm}

What is service learning? It is challenging to find one answer to this question. There are many answers in the literature to define and delimit service-learning. Service-learning is a unique pedagogy as compared to other traditional modes of education. It creates a meaningful link between learning and service. This aspect is absent in different approaches such as lecture, discussion, or other instructional methods used in higher education. The argument based on this understanding is that service learning is an active learning model (Furco, 1996; Sigmon, 1994).

Irrespective of the definitional complexities attached with service-learning, scholars have argued that it is a legitimate, ethical and practical pedagogy for promoting the cause of higher education (Buitn, 2010). Others have characterized it with the '4 Rs' such as respect, reciprocity, reflect and relevance (Sigmon, 1994; Campus Campact, 2000). It implies that those involved in service-learning should respect each other, the culture, and the context of the service. Similarly, the service must benefit all the stakeholders who participate in it, and also the service must be relevant to the content of the course. There are other conceptualizations of servicelearning. For example, earlier Kendall (1990) differentiated between service-learning as a pedagogy to deliver specific content and philosophy as a particular view of the world that permeates curriculum, strategies, and course assessment at different levels of education.

Conversely, Lisman (1998) has declared volunteerism, consumerism, participatory democracy, and social transformation as different modes of service-learning, each method having a different impact on individuals and communities in varying degrees. Other researchers (e.g., 
An analytical review on rethinking service-learning as critical transformative paradigm ...

Liu, 1995; Morton, 1995) have opposed such dichotomization in the service-learning discipline. They argued that these modes of service-learning are collectively helpful in providing valuable service to the community and increased academic learning for students at the higher education level. These perspectives offer useful heuristics for further understanding the different forms of service-learning in various disciplines (Howard, 2000; Butin, 2010). It shows that several distinct problems such as unsupportable ethical foundationalism and teleological considerations are associated with the traditional articulations of service-learning. For example, there are still many questions to be answered. For example, should students in the service-learning be paid for their service? Should students engaged in the community provide service only to the poor or to the rich as well?

A simple answer to the above-mentioned questions is typically grounded in the notion that all individuals are independent change agents who bring about positive and sustained transformations through their worldviews. However, Butin (2010) argues that service-learning balances traditional and modern worldviews through a downward benevolence. As a result, everyone gets benefits who participates in the process of community service. It is believed that service-learning is a pedagogy through which the process and outcomes benefits are equally shared by all those who participate in it. However, some stories tell the opposite. For example, it becomes even more problematic when specific questions are made public such as what actual learning is documented due to service? In addition, there are apprehensions that servicelearning may be helpful for those who perform the existing service, but there is still less evidence that it has much benefited the service recipients (Butin, 2010; Campus Compact, 2003; Kumashiro, 2000). Despite these charges, literature has provided ample evidence about the benefits and transformational potential of service-learning as a pedagogical strategy (Jones, 2002; Rosenberger, 2000; Eyler \& Giles, 1999). The literature review created an excellent ground for discussion and analysis for the transformative aspect of service-learning as community engagement civic pedagogy in higher education.

\section{Discussion}

One of the major goals of higher education is preparing young people for their future roles as responsible, contributing, and active citizens. Educating individuals about future life is a complicated and multifaceted process. It requires developing a particular set of knowledge, skills, and dispositions to actively participate in their societies' democratic process and development. Preparing graduates for their future roles has always rested with educational institutions (Chiva-Bartoll et al., 2019). Dewey proposed that educated citizens should demonstrate habits of engaged participation in developing their societies. Educational institutions have used different teaching and learning methods to achieve this goal. However, since the emergence of service-learning as pedagogy and specifically in the last three decades service-learning has consistently created a synergy for engaging higher education students in real-life experiences. The essential outcomes of service-learning are myriad, such as life skills, civic and leadership development, etc. More recently, service-learning has been declared as critical pedagogy for preparing students for their future roles by improving their knowledge, skills, and dispositions (Mortari \& Ubbiali, 2021).

Service-learning fosters students' social competence, communication skills, problem-solving skills, and civic orientation as a teaching approach in higher education. In the last decade, service-learning proved itself a popular and effective educational strategy that enhances 
students' content knowledge, improves skills, promotes civic responsibility, and prepares them to serve a rapidly changing and highly complicated society as active citizens. Due to this, it has been recognized as an effective method of civic education (Rodríguez-Izquierdo, 2020). Service-learning has been used worldwide to achieve higher education goals: communication, interpersonal skills, leadership, and problem-solving.

The most recent re-emergence of service-learning in critical pedagogy has led to a deeper and broad understanding of the development of students in different fields. For example, as an academic strategy, service-learning helps students better conceptualize course content and realize their role in society as a citizen. Therefore, it has been identified as an effective teaching strategy to achieve the goal of civic development (Lough \& Toms, 2018). Furthermore, one of the unique characteristics of service-learning is its reciprocal nature and its ability to connect academic course content with community service. As a teaching methodology, service-learning provides higher education students practical, meaningful and empowering learning experiences and builds their capacities to become more productive and purposeful for their societies and themselves. Thus, it develops students and citizens by increasing their knowledge, skills, and commitment to serve a rapidly growing complex society.

American Association of Community Colleges (AACC) defines service-learning as an association of community service with classroom instruction to develop students' critical thinking, reflective thinking, personal development, and civic responsibility. In another study, researchers argue that service-learning develops morally and ethically sound citizens who lead others in an equitable way (Lieberman, 2014). The definition provides an excellent foundation for a deeper understanding of service-learning as a civic pedagogy. As a civic pedagogy, service-learning effectively promotes students' leadership skills, critical thinking, decisionmaking, problem-solving, interpersonal, and communication skills. To understand it better, researchers have discussed three components of service-learning. The first is intellectual understanding. This component contains content knowledge, critical thinking, and communication skills. The second is civic skills and attitude. This consists of ethics along with a focus on communities and their general good. The third is civic action. This combines the earlier two to enable the students to act beyond the classroom (Opazo et al., 2016).

Despite the much evidence for positive roles of service-learning, critics charge that servicelearning is not practical. As an educational approach service-learning is expensive, timeconsuming, and resource-demanding. It promotes a liberal social justice agenda that runs counter to a purely academic environment. However, despite the critics' charges, literature is full of evidence that service-learning is positively coo-related with civic development and skills development of students. For example, in a cross-sectional study, students participating in service-learning programs developed positive academic outcomes such as increased civic engagement and life skills. Prentice and Robinson (2007) investigated the effect of service learning on the civic participation of community college students. The study found that students who took part in the service-learning demonstrated a better understanding of their civic responsibility. This supported the findings of earlier studies regarding the role of servicelearning in developing students' civic skills. Another study found that students participating in service-learning gained self-awareness, civic engagement, and leadership skills (Hudin et al., 2018). This supports the views of Dewey that experiential learning develops habits of civic responsibility and increases democratic participation. 
An analytical review on rethinking service-learning as critical transformative paradigm ...

\section{Conclusion}

Service-learning is an incremental and transformational strategy for achieving higher education's civic and democratic goals. One effective way to accomplish this goal is to integrate service-learning in higher education courses as discipline-based pedagogy. This calls for a disciplined approach towards applying theory and practice of service-learning in higher education. This study provides the broader insight that there is no single and binary model through which service-learning could be done for community engagement of higher education students. Different communities have different needs. These needs define the philosophy of the interventions to be made. Hence, the service-learning may be looked at from the multiperspectives rather than a single perspective approach as a community engagement strategy in higher education.

Service-learning is a set of theories rooted in experiential education. However, for a better understanding of service-learning, it is essential to be understood as a social transformation civic and democratic movement rather than merely a curriculum tool to enhance the academic goals of a particular discipline in higher education. Thus, service-learning as a community engagement tool can be used to help develop an engaged university model committed to genuine public engagement by using the community as a laboratory and civic renewal. For this purpose, it is necessary to acknowledge the new role of service-learning for transforming higher education by bridging the limits and extending the possibilities using the transformational reciprocal model of teaching and learning rather than a monolithic one-way approach of traditional classroom environment characterized by lecture and teacher talk at the cost of student development.

\section{References}

American Association of Colleges \& Universities (AAC\&U). (2007). Freedom in the classroom. http://www.aaup.org/AAUP/comm/rep/A/class.htm

Antonio, A. L., Astin, H. S., \& Cress, C. M. (2000). Community service in higher education: A look at the faculty. The Review of Higher Education, 23(4), 373-98. https://muse.jhu.edu/article/30106

Astin, A.W., Sax, L., \& Avalos (1999). Long term effects of volunteerism during the undergraduate years. Review of Higher Education, 22(2), 187-202. https://digitalcommons.unomaha.edu/cgi/viewcontent.cgi?article=1110\&context=s1 cehighered

Baldwin, S.C., Buchanan, A.M., Rudisill, (2007). What teacher candidates learned about diversity, social justice and from service-learning experiences. Journal of Teacher Education, $58(4)$, https://journals.sagepub.com/doi/abs/10.1177/0022487107305259?legid=spite\%3B $\underline{58 \% 2 \mathrm{~F} 4 \% 2 \mathrm{~F} 315 \& \mathrm{rss}=1 \& ; \text { ssource }=\text { mfr \&patientinform-links=yes }}$

Bell, R., Furco,A., Ammon, M.S., Muller, P., \&Sorgen, V. (2000). Institutionalizing higher education in service-learning. University of California.

Bensen, L., Harkavey, I., Puckett, J. (2007). Dewey's dream: Universities and democracies in an age of education reform. Temple University.

Berasategi, N., Alonso, I., \& Roman, G. (2016). Service-learning and higher education: evaluating students learning process form their own perspective. Procedia-Social and 
Behavioral Sciences, 228, 424-429. $\quad$ http://headconf.org/head16/wpcontent/uploads/pdfs/2760.pdf

Berle, D. (2006). Incremental integration: A successful service-learning strategy. International Journal of Teaching and Learning in Higher Education, 18(1), 43-48. http://www.isetl.org/ijtlhe/

Bernstein, D., Burnett, A., Goodburn, A., \& Savory, P. (2006). Making teaching and learning visible: Course portfolios and the peer review of teaching. Anker Publishing. https://digitalcommons.unl.edu/imsefacpub/64/

Borden, A.W. (2007). The impact of service-learning on ethnocentrism in an intercultural communication course. Journal of Experiential Education, 30(2), 171-83. https://wmich.edu/sites/default/files/attachments/u5/2013/Impact\%20of\%20ServiceLearning\%20on\%20Ethnocentrism.pdf

Bringle, R., \& Hatcher, J. (1995). A service learning curriculum for faculty. The Michigan Journal of Community Service-learning 2, 112-22. https://core.ac.uk/download/pdf/46958669.pdf

Bryant, J. A., Schonemann, N., \& Karpa, D. (2011). Integrating service-learning into the university classroom. Jones \& Bartlett. https://www.jblearning.com/catalog/productdetails/9780763780753

Butin, D.W. (2005). Service-learning as Postmodern Pedagog. In D.W Butin (ed), Servicelearning in higher education: Critical issues and directions (pp. 89-104). Palgrave Macmillan. https://link.springer.com/book/10.1057/9781403981042

Butin, D.W. (2006). The limits of service-learning in higher education: The Review of Higher Education, 29(4), 473-98. http://citeseerx.ist.psu.edu/viewdoc/download?doi=10.1.1.392.9924\&rep=rep1\&typ e=pdf

Butin, D.W. (2010). Service-learning in theory and practice: the future of community engagement in higher education. Palgrave Macmillan.

Campus Campact, (2000). President Declaration on the civic responsibility of higher education. Providence, RI: Campus Compact. https://compact.org/resources-forpresidents/presidents-declaration-on-the-civic-responsibility-of-higher-education/

Campus Compact (2003). Introduction to service-learning toolkit: Readings and resources for faculty. (2nd ed.). Providence. RI: Campus Compact. http://www.compact.org/publicaions /s-1_toolkit/intro.html

Campus Compact, (2005). President's declaration on the civic responsibility of higher education. Providence, RI: Campus Compact. https://compact.org/resources-forpresidents/presidents-declaration-on-the-civic-responsibility-of-higher-education/

Chiva-Bartoll, O., Ruiz-Montero, P. J., Martín-Moya, R., Pérez López, I., Giles Girela, J., García-Suárez, J., \& Rivera García, E. (2019). University service-learning in physical education and sport sciences: A systematic review. https://revistas.ucm.es/index.php/RCED/article/download/60191/4564456551767/

Colbeck, C. L., \& Michael, P. W. (2006). Individuals and organizational influences on faculty members' engagement in public scholarships: New Directions for Teaching and Learning 105: 17-26. https://onlinelibrary.wiley.com/doi/abs/10.1002/t1.221

Colby, A., Beamont, E., Ehrlich, T., \& Stephens J. (2007a). Educating for democracy: Preparing undergraduates for important political engagement. Jossey-Bass. https://files.eric.ed.gov/fulltext/ED498989.pdf

Colby, A.T., Beamont, E., Ehrlich, T., \& Stephens, J. (2007b). Educating citizens: Preparing undergraduates for responsible political engagement. Jossey-Bass. 
An analytical review on rethinking service-learning as critical transformative paradigm ...

Conner, J., \& Erickson, J. (2017). When Does Service-Learning Work? Contact Theory and Service-Learning Courses in Higher Education. Michigan Journal of Community Service Learning, 23(2), 53-65.

Cross, B. (2005). New racism, reformed teacher education, and the sole role oppression. Educational Studies, 38(3), 263-74. https://doi.org/10.1207/s15326993es3803_6

Culhane, J., Niewolny, K., Clark, S., \& Misyak, S. (2018). Exploring the Intersections of Interdisciplinary Teaching, Experiential Learning, and Community Engagement: A Case Study of Service Learning in Practice. International Journal of Teaching and Learning in Higher Education, 30(3), 412-422.

Driscroll, A. (2008). Carnegie's community engagement classification, intentions and insights. Change, $40(1)$, $38-41$. https://www.tandfonline.com/doi/abs/10.3200/CHNG.40.1.38-41

Ellison, J., \& Eatman, T.K. (2008). Scholarship in public: Knowledge creation and tenure policy in the engaged university. http://www.imaginingaemrica.org/TTI/TTI/_finalpdf

Ernest, L. B. (1996). The Scholarship of Engagement. Bulletin of the American Academy of Arts and Sciences, 49(7), 18-33. https://doi.org/10.2307/3824459

Esin, C. (2011). Narrative analysis approaches. Qualitative research methods in psychology, 92-118.

Esin, C., Fathi, M., \& Squire, C. (2014). Narrative analysis: The constructionist approach. The SAGE handbook of qualitative data analysis, pp.203-216.

Eyler, J., \& Giles, D. (1999). Where is the learning in the service-learning? Jossey-Bass. https://quod.lib.umich.edu/m/mjcsl/3239521.0006.115/1/--where-s-the-learning-inservice-learning-janet-eyler?page $=$ root; size $=100 ;$ view $=$ text

Eyler, J. (2000). What do we most need to know about the impact of service-learning on student learning? The Michigan Journal of Community Service-learning 7, 11-17.

Folgueiras, P., Aramburuzabala, P., Opazo, H., Mugarra, A., \& Ruiz, A. (2020). Servicelearning: A survey of experiences in Spain. Education, Citizenship and Social Justice, 15(2),

162-180.

https://www.researchgate.net/publication/328604884_Servicelearning_A_survey_of_experiences_in_Spain

Furco, A. (1996). Expanding boundaries: Serving and Learning. Corporation for National Service. http://www.sciepub.com/reference/220721

Furco, A. (2002). Self-assessment rubrics for institutionalization of service-learning in higher education. University of California. https://talloiresnetwork.tufts.edu/wpcontent/uploads/Self-AssessmentRubricfortheInstitutionalizationofServiceLearninginHigherEducation.pdf

Greenhalgh, T., Thorne, S., \& Malterud, K. (2018). Time to challenge the spurious hierarchy of systematic over narrative reviews? European Journal of Clinical Investigation, 48(6), 1-6. https://doi.org/10.1111/eci.12931

Gruslyte, M. (2020). Service-Learning in Higher Education: Experiences of Implementation in Lithuania. In Proceedings of the International Scientific Conference. I(201), p. 210. http://journals.ru.lv/index.php/SIE/article/view/5078

Harkavy, I. (2006). The role of universities in advancing citizenship and social justice in $21^{\text {st }}$ century. Education, Citizenship and Social Justice Research Journal, 39(1), 69100. http://soco-wasow.pbworks.com/f/harkavy06.pdf

Hartley, M., Harkavy, I., \& Bensen, L. (2005). Putting down roots in rows of academe: The challenges of institutionalizing service-learning. In D.W. Butin (ed), Service-learning 
in higher education: Critical issues and directions (pp.205-222). Palgrave Macmillan. https://link.springer.com/book/10.1057/9781403981042

Head, B.W. (2007). Community engagement: Participation on whose terms. Australians Journal of Political Science, 42(3), 441-54. https://www.tandfonline.com/doi/abs/10.1080/10361140701513570

Hildenbrand, S. M., \& Schultz, S. M. (2015). Implementing service learning in pre-service teacher coursework. Journal of Experiential Education,38(3), 262-279. https://naaee.org/eepro/research/library/implementing-service-learning-pre

Hogan, K. (2002). Pitfalls of community-based learning: How power dynamics limit adolescents' trajectories of growth and participation: Teachers College Record, 104(3), 586-98. https://eric.ed.gov/?id=EJ649787

Honnet-Porter, E., \& Poulson, S. (1989). Principles of good practice for combining service and learning. Wingspread special report. The Johnson Foundation. https://nsee.memberclicks.net/assets/docs/KnowledgeCenter/EnsuringQuality/Book sReports/183.\%20principles_of_good_practice_for_combining_service_and_learnin g.pdf

Howard, J. (2000). Academic Service-learning: Myths, Challenges and recommendations. $\begin{array}{llll}\text { Essays on Teaching } & \text { Excellence, }\end{array}$ https://podnetwork.org/content/uploads/V12-N2-Howard.pdf

Hudin, N. S., Osman, J., Shokory, S. M., \& Ab Wahid, H. (2018). Service learning in higher education: Evidence from Malaysia. International Journal of Engineering \& Technology, 7(3.30), 474-479. https://scholar.google.com/citations?user=BjJnqoAAAAAJ\&hl=en

Jones, S.R. (2002). The underside of service-learning. About Campus: Enriching the Student Learning Experience, 7(4), 10-15. https://doi.org/10.1177/108648220200700403

Jones, S.R., Gilbride-Brown, J., \& Gasorki, A. (2005). Getting inside the "underside" of service learning: Student resistance and possibilities. In D.W. Butin (ed), Service-learning in higher education: Critical issues and directions (pp. 205-222). Palgrave Macmillan. https://link.springer.com/book/10.1057/9781403981042

Kendall, J. (1990). Combining service and learning: A resource book for community and public service. Raleigh, NC: National Society for Internships and Experiential Education. https://eric.ed.gov/?id=ED327120

Kezar, A.J., Chambers, T.C., \& Burkhardt, J. eds. (2005). Higher education for the public good: Emerging voices from a national movement. Jossey-Bass.

Kirp, (2003). Shakespeare, Einstein and the bottom line: The marketing of higher education. Harvard https://www.hup.harvard.edu/catalog.php?isbn=9780674016347

University.

Kumashiro. K. K (2000). Against repetition. Addressing resistance to anti-oppressive change in the practices of learning, teaching, supervising, and researching. Harvard Educational Review, 72(1), 67-92. https://doi.org/10.17763/haer.72.1.c1161752617k46v6

Lieberman, D. (2014). The ABCDs of service-learning: Who is serving whom? Journal of Higher Education Outreach and Engagement, 18(4), 7-16. https://openjournals.libs.uga.edu/jheoe/article/view/1155

Lindholm, J.A., Szelenyi, K., Hurtado, S. \& Korn, W.S. (2005). The American college teacher: National norms for the 2004-2005 HERI faculty survey. Sage. https://www.heri.ucla.edu/PDFs/pubs/FAC/Norms/Monographs/TheAmericanColle geTeacher2004To2005.pdf 
An analytical review on rethinking service-learning as critical transformative paradigm ...

Lisman, C.D. (1998). Toward a civic society: Civic literacy and service learning. Bergin and Garvey.

Liu, G. (1995). Knowledge, Foundations and discourse: philosophical support for servicelearning. The Michigan Journal for Community Service-learning, 2(2), 5-18. https://eric.ed.gov/?id=EJ552423

Lorenzo, C., \& Lorenzo, E. (2019). Opening up higher education: An e-learning program on service-learning for university students. In International Conference on Applied Human Factors and Ergonomics (pp. 27-38). Springer, Cham. https://link.springer.com/book/10.1007/978-3-030-20135-7

Lough, B. J., \& Toms, C. (2018). Global service-learning in institutions of higher education: concerns from a community of practice. Globalization, Societies and Education, 16(1), 66-77. https://www.tandfonline.com/doi/abs/10.1080/14767724.2017.1356705

Lucas, C.J. (1996). Crisis in the academy: Rethinking higher education in America. St. Marin's Press.

Markus, G., Howard, J., \& King, D. (1993). Integrating community service and classroom instruction enhances learning: Results from an experimental Educational Evaluation and Policy Analysis, 15, 410-419. https://www.jstor.org/stable/1164538

McKnight, J. (1998). Why 'servanthood' is bad. The other side (January/ February): 38-41. https://mn.gov/mnddc/mcKnight/documents/Why_Servanthood_is_Bad.pdf

Melchior, A. (2000). Service-learning at your service. Education Digest, 66(2), 26-32. https://www.proquest.com/openview/8a88bc6180be92a1669817f804385b32/1.pdf? pq-origsite $=$ gscholar \&cbl $=25066$

Mitchell, T.D. (2007). Critical service-learning as social justice education: A case study of the citizens' scholars program. Equity and Excellence in Education, 40(2), 101-12. https://www.tandfonline.com/doi/abs/10.1080/10665680701228797

Morgan, W., \& Streb, M. (2001). Building citizenship. How student voice in service-learning develops civic values. Social Science Quarterly, 82(1), 154-170. https://digitalcommons.unomaha.edu/cgi/viewcontent.cgi?article=1087\&context=s1 ceslgen

Mortari, L., \& Ubbiali, M. (2021). Service Learning: A Philosophy and Practice to Reframe Higher Education. Athens Journal of Education, 8(2), 115-138. https://www.athensjournals.gr/education/2021-8-2-1-Mortari.pdf

Morton, K. (1995). The irony of service: Charity, project and social change in service-learning. The Michigan Journal of Service-Learning, 2, 19-32. https://quod.lib.umich.edu/m/mjcsl/3239521.0002.102/1/--irony-of-service-charityproject-and-social-change?page $=$ root; size $=100 ;$ view $=$ text

National Commission on Service Learning (N.D). Learning in Deeds: The Power of ServiceLearning for American Schools. https://ed253jcu.pbworks.com/f/LearningDeedServiceLearning_American+Schools. PDF

O'Grady, C.R. ed. (2000). Integrating service-learning and multicultural education in colleges and universities. Lawrence Erlbaum. https://www.routledge.com/IntegratingService-Learning-and-Multicultural-Education-in-Collegesand/OGrady/p/book/9780805833454

Opazo, H., Aramburuzabala, P., \& Cerrillo, R. (2016). A Review of the Situation of ServiceLearning in Higher Education in Spain. Asia-Pacific Journal of Cooperative Education, 17(1), 75-91. 
https://www.researchgate.net/publication/299854162_A_Review_of the_Situation of Service-Learning in_Higher_Education_in_Spain

Paoletti, J.B., Segal, E., \& Tonito, C. (2007). Acts of diversity: Assessing the impact of servicelearning. New Directions for Teaching and Learning, 111, 47-54. https://eric.ed.gov/?id=EJ775972

Paul, E. L. (2006). Community based research as scientific and civic pedagogy. Peer Review, $8(1), \quad 68-76 . \quad$ https://www.aacu.org/publications-research/periodicals/communitybased-research-scientific-and-civic-pedagogy

Pompa, L. (2002). Service-learning as crucible. Michigan Journal of Community ServiceLearning, 9(1), 67-76. http://hdl.handle.net/2027/spo.3239521.0009.107

Pompa, L. (2005). Service-learning as crucible. Reflections on immersion, context, power and transformation. In D.W. Butin (ed) (2005), Service-learning in higher education: Critical issues and directions (pp. 173-192). Palgrave Macmillan.

Prentice, M., \& Robinson, G. (2007). Linking Service Learning and Civic Engagement in Community College Students. American Association of Community Colleges (NJ1). https://files.eric.ed.gov/fulltext/ED503445.pdf

Ramaley, J.A. (2006). Public scholarship: Making sense of an emerging synthesis. New Directions for Teaching and Learning, 105, 85-97. https://digitalcommons.unomaha.edu/cgi/viewcontent.cgi?article=1175\&context=sl cehighered

Resch, K., Fellner, M., Fahrenwald, C., Slepcevic-Zach, P., Knapp, M., \& Rameder, P. (2020). Embedding Social Innovation and Service Learning in Higher Education's Third Sector Policy Developments in Austria. In Frontiers in Education (Vol. 5, p. 112). Frontiers. https://www.frontiersin.org/articles/10.3389/feduc.2020.00112/full

Rhoads, R.A. (1997). Community service and higher learning: Explorations of the caring self. State University of New York. https://www.journals.uchicago.edu/doi/abs/10.1086/210160

Rodríguez-Izquierdo, R. M. (2020). Service learning and academic commitment in higher education. Revista de Psicodidáctica (English ed.), 25(1), 45-51. https://www.researchgate.net/publication/338078470_Service_Learning_and_acade mic_commitment_in_Higher_Education

Rosenberger, C. (2000). Beyond Empathy: Developing critical consciousness through servicelearning. In C.R. O'Grady (Ed.), Integrating service-learning and multicultural education in colleges and universities. 22-44

Saeed, M., \& Ahmed, I. (2021). Using Service-Learning Approach for Promoting High-Order Thinking Skills Among Pakistani Pre-Service Teachers. Journal of Humanities, Social and Management Sciences (JHSMS), 2(1), 187-199. https://doi.org/10.47264/idea.jhsms/2.1.16

Salam, M., Iskandar, D. N. A., Ibrahim, D. H. A., \& Farooq, M. S. (2019). Service learning in higher education: A systematic literature review. Asia Pacific Education Review, 20(4), 573-593. https://eric.ed.gov/?id=EJ1233852

Schutz, A. (2006). Home is a prison in the global city: The tragic failure of school-based community engagement strategies. Review of Educational Research, 76(6), 691-743. https://journals.sagepub.com/doi/10.3102/00346543076004691

Sigmon, R. (1994). Serving to learn, learning to serve. In Council for Independent Colleges Report. The Council of Independent Colleges. https://eric.ed.gov/?id=ED446685

Swaminathan, R., (2007). Education for real world: The hidden curriculum of community service-learning. Equity \& Excellence in Higher Education, 40(2), 134-43. 
An analytical review on rethinking service-learning as critical transformative paradigm ...

https://www.researchgate.net/publication/232843772_Educating_for_the_Real_Wor ld_The_Hidden_Curriculum_of_Community_Service-Learning

Taylor, A., \& Kahlke, R. (2017). Institutional Logics and Community Service-Learning in Higher Education. Canadian Journal of Higher Education,47(1), 137-152. https://journals.sfu.ca/cjhe/index.php/cjhe/article/download/187377/pdf/

Tian, Q., \& Noel Jr, T. (2020). Service-Learning in Catholic Higher Education and Alternative Approaches Facing the COVID-19 Pandemic. Journal of Catholic Education, 23(1), 184-196. https://digitalcommons.lmu.edu/ce/vol23/iss1/13/

Tijsma, G., Hilverda, F., Scheffelaar, A., Alders, S., Schoonmade, L., Blignaut, N., \& Zweekhorst, M. (2020). Becoming productive 21st century citizens: A systematic review uncovering design principles for integrating community service learning into higher education courses. Educational Research, 62(4), 390-413. https://www.tandfonline.com/doi/full/10.1080/00131881.2020.1836987

Varolta, L.E. (1997). A critique of service-learning's definitions, continuums, and paradigms: A move towards a discourse-praxis community. Educational Foundations, 11(3), 5385. https://eric.ed.gov/?id=EJ553090

Vaughn, R. L., \& Seifer, S.D. (2008). Recognizing service-learning in higher education through minors and certificates. In Community-Campus Partnerships for health. Retrieved from http://www.servicelearning.org/instant_info/fact)sheet/he_certs/he

Wade, R.C. (2007). Service-learning for social justice in the elementary classroom: Can we get there from here? Equity and Excellence in Education, 40(2), 156-65. https://www.tandfonline.com/doi/abs/10.1080/10665680701221313

Warren-Gordon, K., \& Graff, C. S. (2018). Critical Service-Learning as a vehicle for change in higher education courses. Change: The Magazine of Higher Learning, 50(6), 2023. https://www.tandfonline.com/doi/abs/10.1080/00091383.2018.1540817

Young, C.A., Shinaar, R.L., Ackerman, C.P., Carruthers \& Young D.A. (2007). Implementing and sustaining service-learning at the institutional level. Journal of Experiential Education, $\quad 29 \quad$ (3), 344-65. https://journals.sagepub.com/doi/abs/10.1177/1053825916629987

Zemsky, R., Wegner, G.R., \& Massy, W.F. (2005). Remaking the American university: Market-smart and mission-centered. Rutgers University. https://www.amazon.com/Remaking-American-University-Market-Smart-Mission-

Zlotowski, E. (1995). Does service-learning have a future? The Michigan Journal of Servicelearning 2 ,

123-33. http://scholarworks.umb.edu/cgi/viewcontent.cgi?article=1015\&context=nerche pu $\underline{\mathrm{bs}}$ 